\title{
A ritka kromoszóma-rendellenességek és a fetoplacentaris mozaikosság jelentősége a praenatalis diagnosztikában a nem invazív szüróvizsgálatok tükrében
}

\author{
Tidrenczel Zsolt dr. ${ }^{1}$ - P. Tardy Erika dr. ${ }^{2}$ - Böjtös Ildikó ${ }^{2}$ \\ Sarkadi Edina ${ }^{2}$ - Simon Judit dr. ${ }^{2}$ - Pikó Henriett dr. ${ }^{3}$ \\ Vermes Gábor dr. ${ }^{1}$ - Demeter János dr. ${ }^{1}$ - Beke Artúr dr. ${ }^{4}$
}

\author{
${ }^{1}$ Magyar Honvédség Egészségügyi Központ, Szülészet-Nőgyógyászati Osztály, Genetikai Centrum, Budapest \\ ${ }^{2}$ Magyar Honvédség Egészségügyi Központ, Központi Laboratóriumi Diagnosztikai Osztály, Budapest \\ ${ }^{3}$ Semmelweis Egyetem, Általános Orvostudományi Kar, \\ PentaCore Laboratórium és I. Belgyógyászati Klinika, Budapest \\ ${ }^{4}$ Semmelweis Egyetem, Általános Orvostudományi Kar, Szülészeti és Nőgyógyászati Klinika, Budapest
}

\begin{abstract}
Bevezetés és célkitüzés: A gyakori autoszomális trisomiák és a nemi kromoszómaeltérések a mikroszkóppal észlelhető kromoszóma-rendellenességek kb. 80-85\%-át képviselik. A ritka kromoszóma-rendellenességek klinikai következménye jelentős, kimutatásukat a jelenlegi szưrővizsgálatok ugyan nem célozzák, de a teljes kromoszómaszerelvényt vizsgáló, nem invazív praenatalis tesztelés új lehetőséget nyitott a korai felismerésükre.

Módszer: Retrospektív analízis (2014-2019) a mikroszkóppal kimutatható kromoszóma-rendellenességek eloszlására, a fetoplacentaris mozaikosság előfordulására, klinikai összefüggéseire a praenatalis vizsgálatok tükrében egy hazai tercier centrumban.

Eredmények: 2504 invazív beavatkozást végeztünk és 200 kromoszómaeltérést mutattunk ki (8\%), melyek közül újonnan kialakult, ritka rendellenesség 27 volt $(13,5 \%)$. Ritka autoszomális trisomia 14, poliploidia 6 , de novo szerkezeti kromoszómaeltérés 5, marker kromoszóma 2 esetben igazolódott. A fetoplacentaris mozaikosság aránya a gyakori/ritka kromoszómaeltérésekben $12,4 \% / 77,8 \%$ volt $(\mathrm{p}=0,001), 17 / 40$ esetben lepényre korlátozódott. A gyakori trisomiákkal kóros tarkóredő-vastagság 58\%-ban, major ultrahangeltérés 35\%-ban társult, melyek jelentősen különböztek a ritka kromoszómaeltérésekben $(11 \%, p=0,006 ; 67 \%, p=0,047)$. A ritka kromoszómaeltérések jellemző praenatalis major ultrahangeltérése a facialis dysmorphismus volt. A teljes kromoszómaszerelvényt vizsgáló praenatalis tesztelés a ritka kromoszómaeltérések 12 lepényi mozaikos esetében (44\%) feltételezhetően álpozitív, 1 esetben $(3,7 \%)$ álnegatív eredményt generált volna, miközben a ritka autoszomális trisomiák 2 esetében ultrahangeltérés nélkül is korán detektálta volna a ritka magzati kromoszómaeltérést $(7,4 \%)$.

Következtetés: A normális tarkóredő-vastagság esetén észlelt major ultrahangeltérések felhívhatják a figyelmet a döntően mozaikos ritka kromoszóma-rendellenességekre. A teljes kromoszómaszerelvényt vizsgáló, nem invazív szúrőteszt a korai diagnosztika alternatívája lehet, a mozaikosságból adódó álpozitív eredményekre azonban számítani kell. A fetoplacentaris mozaikosság ismerete fontos klinikai információt biztosít, mely befolyásolhatja a terhesség kimenetelét, a terhesség követésének módját. A pontos citogenetikai karakterizálás elengedhetetlen.

Orv Hetil. 2021; 162(29): 1156-1165.
\end{abstract}

Kulcsszavak: praenatalis ultrahangvizsgálat, mozaikosság, ritka autoszomális trisomia, NIPT, arrayCGH

The significance of rare chromosomal abnormalities and fetoplacental mosaicism in prenatal diagnosis in the non-invasive prenatal testing era

Introduction and objective: To determine the prevalence of microscopically visible de novo atypical chromosomal aberrations and fetoplacental mosaicism in a prenatal tertial referral center, and to investigate the maternal and fetal characteristics in connection with genomewide non-invasive prenatal screening.

Method: Retrospective cohort study from 2014 to 2019 of pregnancies with invasive genetic analysis. 
Results: In the cohort of 2504 cases, the proportion of CVS was 53.3\%. We diagnosed 200 chromosomal aberrations (8\%), including $13.5 \%$ of de novo rare chromosomal aberrations ( 14 rare autosomal trisomies, 6 polyploidies, 5 structural aberrations and 2 small supernumerary marker chromosomes). The rate of fetoplacental mosaicism was $12.4 \% / 77.8 \%$ in common/atypical chromosomal aberrations $(\mathrm{p}=0.001)$ and confined to placenta in $17 / 40$ cases. Associated ultrasound abnormalities were abnormal nuchal translucency and major malformations in $58 \%$ and $35 \%$ with common trisomies and $11 \%(\mathrm{p}=0.006)$ and $67 \%(\mathrm{p}=0.047)$ with true mosaic cases of rare abnormalities, respectively. Major ultrasound malformation was facial dysmorphism with rare aberrations. Potential application of genomewide non-invasive prenatal test in atypical chromosomal aberrations presumably would have been false-positive in 12 cases $(44 \%)$, false-negative in 1 case $(3.7 \%)$, and would have early detected 2 cases of rare autosomal trisomies $(7.4 \%)$ without ultrasound anomalies.

Conclusion: Structural ultrasound malformations with normal nuchal translucency thickness may be indicative of rare chromosomal aberrations. Application of genomewide non-invasive prenatal test is an alternative of early diagnostic methods with a potential of discordant results due to mosaicism. Knowledge about the presence of fetoplacental mosaicism influences risk estimation and genetic counseling, detailed cytogenetic characterization is of utmost importance.

Keywords: prenatal ultrasound, mosaicism, rare autosomal trisomy, NIPT, arrayCGH

Tidrenczel Zs, P. Tardy E, Böjtös I, Sarkadi E, Simon J, Pikó H, Vermes G, Demeter J, Beke A. [The significance of rare chromosomal abnormalities and fetoplacental mosaicism in prenatal diagnosis in the non-invasive prenatal testing era]. Orv Hetil. 2021; 162(29): 1156-1165.

(Beérkezett: 2020. október 28.; elfogadva: 2021. január 8.)

\begin{abstract}
Rövidítések
$\mathrm{aCGH}=$ (microarray comparative genome hybridization $)$ microarray-komparatív genomhibridizálás; arrayCGH = (chromosomal microarray comparative genome hybridization) kromoszomális microarray-komparatív genomhibridizálás; $\mathrm{CNV}=$ (copy number variations) kópiaszám-variáció; $\mathrm{CPM}=$ (confined placental mosaicism) lepényre korlátozódó mozaikosság; $\mathrm{CVS}=$ (chorionic villous sampling) lepényszövet-mintavétel; DNS = dezoxiribonukleinsav; FISH = fluoreszcens in situ hibridizáció; FMF = (Fetal Medicine Foundation $)$ Magzati Orvoslás Alapítvány; $\mathrm{Mb}=$ megabázis; MSZNUT = Magyar Szülészet-Nógyógyászati Ultrahang Társaság; NEAK = Nemzeti Egészségbiztosítási Alapkezelő; NIPT = (non-invasive prenatal testing) nem invazív praenatalis tesztelés; $\mathrm{NT}=$ (nuchal translucency) tarkóred”o-vastagság; PAPP-A = (pregnancy-associated plasma protein-A) terhességgel összefüggó plazmafehérje-A; qfPCR = (quantitative fluorescent polymerase chain reaction) kvantitatív fluoreszcens polimeráz-láncreakció; SCA $=$ (sex chromosome aneuploidy) nemi kromoszómarendellenesség; SNP = (single nucleotid polymorphism) egyszeres nukleotidpolymorphysmus; $\mathrm{sSMC}=$ (small supernumerary marker chromosome) kis méretű számfeletti marker kromoszóma; TFM = (true fetal mosaicism) valódi magzati mozaikosság; USA $=($ United States of America $)$ Amerikai Egyesült Államok
\end{abstract}

Az invazív méhüregi beavatkozások során (lepényszövetmintavétel, magzatvíz-mintavétel, magzati vérvétel) alkalmazott hagyományos kromoszómavizsgálat évtizedek óta a praenatalis diagnosztika arany standard módszere $[1,2]$. A klasszikus G-sávos kromoszómafestési technika használatát ugyanakkor a mikroszkópos vizsgálat felbontási képessége behatárolja, így az 5-10 Mb alatti méretú, ún. szubmikroszkópos kromoszómaeltérések nem észlelhetők. A klasszikus kariotipizálás mellett - a gyors, célzott diagnosztikára alkalmas molekuláris genetikai módszerek közül - a fluoreszcens in situ hibridizáció (FISH) és a kvantitatív fluoreszcens polimeráz-láncreakció (qfPCR) a hazai centrumokban is rutinszerúen alkalmazott metodika $[3,4]$. Az elmúlt évtized újdonsága a microarray-komparatív genomhibridizálás (arrayCGH, aCGH) bevezetése és elterjedése volt a praenatalis diagnosztikában, amely a szubmikroszkópos, $10 \mathrm{Mb}$ mérettartomány alatti DNS-többletek és -hiányok, kópiaszámvariációk $(\mathrm{CNV})$ gyors, megbízható vizsgálatára alkalmas. A módszer felhasználása azon esetekben, amikor szervi magzati ultrahangeltérés igazolható, körülbelül 5-7\% többlet genetikai információval szolgál a hagyományos kromoszómavizsgálattal szemben $[5,6]$. Ugyanakkor az anyai vérben szabadon keringő, sejtmentes, lepényi trophoblastsejt eredetû́ DNS-fragmentumok újgenerációs szekvenálással történő elemzése (nem invazív praenatalis tesztelés, NIPT) forradalmasította a praenatalis szúrést [7], és világszerte az invazív beavatkozások számának drasztikus csökkenését eredményezte [8].

A számbeli kromoszóma-rendellenességek többsége a gyakori aneuploidiák közé tartozik, melyek döntően a testi kromoszómák trisomiái vagy a gonosomák számbeli rendellenességei. Ugyanakkor a leggyakrabban elöforduló 21-es trisomia (T21, Down-szindróma) is csak kb. 50\%-át képviseli az összes magzati kromoszómaeltérésnek, a 18-as (T18, Edwards-szindróma) és a 13-as (T13, Patau-szindróma) trisomiával együtt is csak a kétharmadát. A kromoszómaeltérések kb. 15-20\%-a azonban az ún. ritka rendellenességek közé tartozik $[9,10]$, melyek korai szúrésére újabban a teljes kromoszómaszerelvényt vizsgáló (genomewide) NIPT kínál lehetőséget [11]. 
A kromoszomális mozaikosság a praenatalis diagnosztika egyik komoly kihívását jelenti. Mozaikosság esetén az egyén szerveiben és szöveteiben egyszerre több, különböző kromoszómaállományú sejtvonal található. A praenatalis vizsgálatok során a lepényi eredetû trophoblast- és mesenchymalis sejtekben, illetve a magzatvízben található amniocytákban az egyes sejtvonalak menynyisége és eloszlása határozza meg a mozaikosság típusát. $\mathrm{Az}$ adott sejtben vagy szövetben igazolt kromoszómaeloszlás alapján lepényre korlátozódó mozaikosságot (CPM) vagy valódi magzati mozaikosságot (TFM) különböztetünk meg $[12,13]$, melyek gyakorisága jelentősen eltérhet egymástól az egyes kromoszóma-rendellenességekben [14-16]. A fetoplacentaris mozaikosság ráadásul a szúrőtesztek diszkordáns eredményeiért is jelentős mértékben felelős lehet [17].

Tanulmányunk célja az volt, hogy egy praenatalis magyarországi centrum anyagában megvizsgáljuk a gyakori és a ritka, mikroszkóppal kimutatható kromoszómarendellenességek eloszlását, a fetoplacentaris mozaikosság előfordulását és klinikai összefüggéseit.

\section{Anyag és módszer}

Tanulmányunk a Magyar Honvédség Egészségügyi Központ Genetikai Centrumában retrospektív módon vizsgálta részlegünk adatbázisában a 2014 és 2019 között invazív beavatkozással (lepényszövet-mintavétel, CVS; amniocentesis) kimutatott, mikroszkóppal észlelhető magzati kromoszóma-rendellenességeket.

Az invazív beavatkozás indikációi a következők voltak: az anyai életkor 37 év felett, ultrahangeltérés (minor vagy major), terhelő genetikai vagy családi anamnézis, kóros biokémiai szürési lelet (kombinált, integrált teszt), kóros NIPT-lelet, valamint a szülőkben kiegyensúlyozott szerkezeti kromoszóma-rendellenesség hordozása. CVS-t a 11. és 20. terhességi hét között, amniocentesist a 15. és 20. hét között végeztünk. Centrumunk a korai magzati diagnosztikára törekszik, ezért a fó választandó beavatkozás a CVS volt. Késői jelentkezés, késői ultrahang- vagy szűrővizsgálati eltérések, a lepény kedvezőtlen helyzete és mozaikos CVS-eredmény esetén amniocentesist végeztünk. Mozaikos kromoszómaeltérés esetén a CPM/TFM meghatározását egy 6 típust elkülönítő klasszifikációs rendszer szerint elemeztük [9]. Ritka szerkezeti kromoszóma-rendellenesség esetén a de novo jelleg igazolására a szülők kariotipizálását is elkészítettük.

A magzati ultrahangvizsgálatokat a Magyar SzülészetNőgyógyászati Ultrahang Társaság (MSZNUT) aktuálisan érvényes protokollja szerint, GE Voluson 730 Expert és E8 készülékeken (GE Healthcare, Chicago, IL, USA), a Fetal Medicine Foundation (FMF) által akkreditált vizsgálók végezték. Az ultrahangeltéréseket minor gyanújelek vagy major, szervi eltérések csoportjába soroltuk. Az első trimeszteri ultrahangeltérések a következők voltak: magzati tarkóredő-vastagság $(\mathrm{NT})>3 \mathrm{~mm}$, az orrcsont hiánya, a ductus venosus kóros áramlása. A máso- dik trimeszteri minor jelek az alábbiak voltak: magzati tarkópárna >6 mm, az orrcsont/prenazális rés kóros aránya, plexus chorioideus cysta, enyhe/mérsékelt agykamratágulat (10-15 mm), rövid csöves csontok (<10 percentilis), pyelectasia $(>4 \mathrm{~mm})$, echogén papillaris izom a szívben, echogén magzati belek és arteria umbilicalis singularis. A major ultrahangeltérések a következők voltak: cysticus hygroma, hydrops, központi idegrendszeri, szív-, hasüregi, hasfali, urogenitalis és végtagi eltérések.

A lepényi és a magzatvízminták tenyésztése és feldolgozása standard metodikák alapján történt [18]. A mikroszkópos preparátumok kiértékeléséhez G-, alkalmanként C- és Q-sávtechnikát alkalmaztunk. FISH-technikát használtunk a leggyakoribb aneuploidiák kimutatására (Prenatal Enumeration Kit; Cytocell Ltd., Cambridge, Egyesült Királyság). A ritka kromoszómaeltéréseket szubtelomerikus FISH-próbák segítségével pontosítottuk a gyártó cég ajánlásával (TeloMark Kit, Cytocell Ltd.). Amennyiben az észlelt kromoszóma-rendellenesség jellege megkövetelte (például a felbontási határhoz közeli méretü kromoszómaeltérés, marker kromoszóma, a pontos töréspont-meghatározás igénye, komplex kromoszóma-átrendeződés esetén), a házaspárnak javasoltuk az önköltséges aCGH-vizsgálatot. Az egyszeres nukleotidpolymorphysmus (SNP) microarray-analízise a teljes genomot lefedi, és különösen nagy lefedettséget használ 396 olyan genomi régióra, melynek kiemelt jelentősége van a praenatalis és a perinatalis kutatásban (CytoScan Optima platform; Affymetrix, Santa Clara, CA, USA).

Az alábbi kromoszóma-rendellenességeket vizsgáltuk: - Gyakori kromoszómaeltérések: autoszomális trisomiák (T21, T18, T13); nemi kromoszóma-rendellenességek.

- Ritka, de novo kromoszómaeltérések: poliploidia (triploidia, tetraploidia); újonnan kialakult, de novo szerkezeti kromoszóma-rendellenességek (strukturális de novo); ritka autoszomális trisomiák; kis méretü számfeletti marker kromoszóma (sSMC).

- Ritka, familiáris kromoszómaeltérések: szülőtől örökölt, szerkezeti kromoszóma-rendellenességek (például transzlokáció, inverzió, strukturális pat/mat).

A statisztikai feldolgozást SAS 9.4 programmal (SAS Institute, Cary, NC, USA) végeztük. A leíró statisztikában folyamatos változók esetén (életkor, terhességi hetek) átlagot és szórást határoztunk meg 95\%-os konfidenciaintervallummal, kategorikus változók esetén a gyakoriság összes elemszámra vonatkoztatott hányadosát fejeztük ki \%-ban. Folyamatos változók esetén kétmintás t-próbát, kategorikus változók esetén khi-négyzet-próbát alkalmaztunk. A p $<0,05$ értékét tekintettük szignifikánsnak.

\section{Eredmények}

2014 és 2019 között 2504 invazív beavatkozást végeztünk, melyek közül 1334 esetben CVS és 1170 esetben amniocentesis történt. A CVS/amniocentesis arány 
$53,3 \% / 46,7 \%$ volt $(\mathrm{p}=0,001) .200$ esetben igazoltunk kromoszóma-rendellenességet (8\%). A gyakori kromoszómaeltérések csökkenő sorrendben a következők voltak: Down-szindróma (92 eset, 46\%); Edwards-szindróma (31 eset, 15,5\%); nemi kromoszóma-rendellenességek (22 eset, 11\%); Patau-szindróma (8 eset, 4\%). Ritka kromoszómaeltérést 47 esetben észleltünk, melyek a kromoszóma-rendellenességek 23,5\%-át tették ki. Poliploidia $6(3 \%)$, de novo szerkezeti kromoszómaeltérés (strukturális de novo) $5(2,5 \%)$, ritka autoszomális trisomia 14 (7\%) és sSMC 2 (1\%) esetben volt kimutatható. De novo, tehát újonnan kialakult ritka kromoszómarendellenesség így 27 esetben volt kimutatható $(27 / 2504=1,07 \%, 27 / 200=13,5 \%)$. A ritka rendellenességeken belül 20 esetben $(10 \%)$ anyai vagy apai eredetú, szülőtől örökölt kromoszomális transzlokációt/ inverziót (strukturális pat/mat) találtunk (1. ábra és 1 . táblázat). A kromoszóma-rendellenességek 76\%-a a ko-

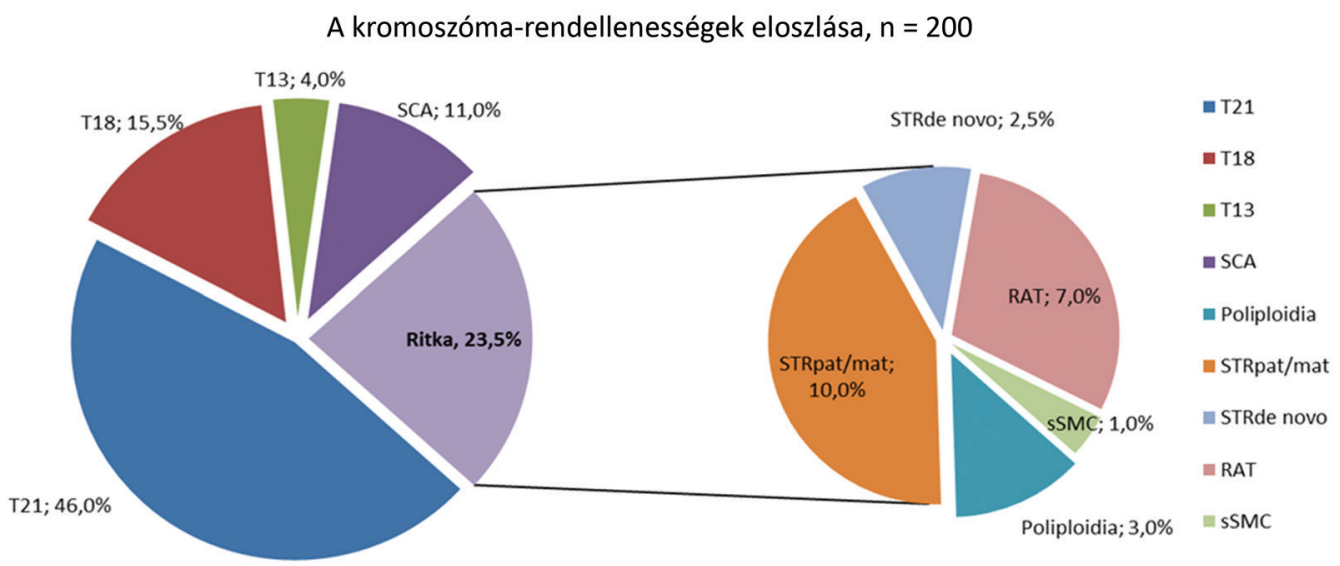

1. ábra

A praenatalisan igazolt magzati kromoszóma-rendellenességek típusai és eloszlása 2014 és 2019 között

$\mathrm{RAT}=$ ritka autoszomális trisomiák; $\mathrm{SCA}=$ nemi kromoszómarendellenesség; $\mathrm{sSMC}=$ kis méretû számfeletti marker kromoszóma; STRde novo $=$ strukturális de novo; STRpat $/ \mathrm{mat}=$ strukturális pat $/ \mathrm{mat} ; \mathrm{Tl} 3=13$-as trisomia; T18 = 18-as trisomia; T21 = 21-es trisomia

1. táblázat | A kromoszóma-rendellenességek előfordulása és a klinikai jellemzók. A táblázat a kromoszóma-rendellenességek eloszlását, a diagnózis felállításához használt invazív beavatkozások (CVS, amniocentesis) egymáshoz viszonyított arányát, az anyai átlagéletkort, a diagnosztikus módszer idejében mérhető terhességi heteket és a diagnózis felállításához használt genetikai módszereket tartalmazza az adott kromoszómaeltérésekben

\begin{tabular}{|c|c|c|c|c|c|}
\hline $\begin{array}{l}\text { A kromoszómaeltérés } \\
\text { típusa }\end{array}$ & $\begin{array}{l}\mathrm{n} \\
(\mathrm{db}, \%)\end{array}$ & $\begin{array}{l}\text { Anyai átlagéletkor } \\
\text { (év, CI 95\%) }\end{array}$ & $\begin{array}{l}\text { CVS / amniocentesis } \\
\text { arány }\end{array}$ & $\begin{array}{l}\text { A terhesség átlagideje } \\
\text { a diagnóziskor } \\
\text { (hét, CI 95\%) }\end{array}$ & $\begin{array}{l}\text { A diagnózishoz } \\
\text { használt genetikai } \\
\text { módszer }\end{array}$ \\
\hline $\begin{array}{l}\text { Gyakori } \\
\text { kromoszómaeltérés }\end{array}$ & $\begin{array}{l}153 \\
(76,5 \%)^{*}\end{array}$ & $\begin{array}{l}36,3 \\
(35,2-37,4)\end{array}$ & $2,56^{* *}$ & $\begin{array}{l}13,8 \\
(13,4-14,2) * * *\end{array}$ & \\
\hline $\mathrm{T} 21$ & 92 & 36,6 & 3 & 14,2 & Kario, FISH \\
\hline T18 & 31 & 38 & 1,21 & 13,1 & Kario, FISH \\
\hline $\mathrm{T} 13$ & 8 & 35 & 1,67 & 12,8 & Kario, FISH \\
\hline Nemi kromoszomális rendellenesség & 22 & 36 & 6,3 & 14 & Kario, FISH \\
\hline $\begin{array}{l}\text { Ritka, de novo } \\
\text { kromoszómaeltérés }\end{array}$ & $\begin{array}{l}27 \\
(13,5 \%) *\end{array}$ & $\begin{array}{l}35,5 \\
(33,1-37,9)\end{array}$ & $1 * *$ & $\begin{array}{l}16,1 \\
(15,2-17) * * *\end{array}$ & \\
\hline Poliploidia & 6 & 36 & 1,5 & 15 & Kario, FISH \\
\hline Strukturális de novo & 5 & 35,6 & 0.75 & 15,8 & Kario, aCGH, FISH \\
\hline Ritka autoszomális trisomia & 14 & 34,8 & 1 & 16,4 & Kario, aCGH, FISH \\
\hline sSMC & 2 & 39 & 0,5 & 18 & $\begin{array}{l}\text { Kario, MFISH, } \\
\text { aCGH }\end{array}$ \\
\hline $\begin{array}{l}\text { Ritka, familiáris } \\
\text { kromoszómaeltérés } \\
\text { (strukturális pat/mat) }\end{array}$ & $\begin{array}{l}20 \\
(10 \%)^{*}\end{array}$ & $\begin{array}{l}35,5 \\
(34,4-36,6)\end{array}$ & 9 & $\begin{array}{l}13 \\
(12,2-13,8)\end{array}$ & Kario, aCGH, FISH \\
\hline
\end{tabular}

${ }^{*} \mathrm{p}=0,001,{ }^{* *} \mathrm{p}=0,001,{ }^{* *} \mathrm{p}=0,00001$

aCGH = microarray-komparatív genomhibridizálás; CI = konfidenciaintervallum; CVS = lepényszövet-mintavétel; Kario = kariotipizálás; (M)FISH = (multicolour) fluoreszcens in situ hibridizáció; sSMC = kis méretû számfeletti marker kromoszóma; T13 = 13-as trisomia; T18 = 18-as trisomia; T21 = 21-es trisomia 
A fetoplacentaris mozaikosság típusai és gyakorisága a praenatalis vizsgálatok során a gyakori és a ritka kromoszóma-rendellenességekben. A táblázat ban a gyakori és a ritka kromoszóma-rendellenességekben a mozaikos esetek aránya, a lepényszövet-mintavételre (CVS) és az amniocentesisre vonatkoztatott gyakorisága, illetve a mozaikos esetek eloszlása látható lepényre korlátozódó (CPM) és valódi magzati mozaikosság (TFM) esetén (n, \%)

\begin{tabular}{lllcc}
\hline A kromoszómaeltérés típusa & $\begin{array}{l}\text { Mozaikos esetek } \\
(\mathrm{n}, \%)\end{array}$ & Mozaikos eset / CVS & $\begin{array}{l}\text { Mozaikos eset } \\
\text { amniocentesis }\end{array}$ & CPM \\
\hline $\begin{array}{l}\text { Gyakori } \\
\text { kromoszómaeltérés }\end{array}$ & $\begin{array}{l}19 / 153 \\
(12,4 \%)^{*}\end{array}$ & $16(10,4 \%)^{* *}$ & $3(2 \%)^{* *}$ & $5(3,3 \%)^{* * *}$ \\
\hline $\begin{array}{l}\text { Ritka, de novo } \\
\text { kromoszómaeltérés }\end{array}$ & $\begin{array}{l}21 / 27 \\
(77,8 \%)^{*}\end{array}$ & $20(74 \%)^{* *}$ & $9(33,3 \%)^{* *}$ & $12(44,5 \%)^{* * *}$ \\
\hline $\begin{array}{l}\text { Ritka, familiáris } \\
\text { kromoszómaeltérés }\end{array}$ & $0 / 20$ & - & - & - \\
\hline Összesen & $40 / 200(20 \%)$ & $36 / 1334(2,7 \%)^{* *}$ & $12 / 1170(1 \%)^{* *}$ & $17 / 200(8,5 \%)^{* * *} 23 / 200(11,5 \%)^{* * *}$ \\
\hline
\end{tabular}

${ }^{*} \mathrm{p}=0,001,{ }^{*} \mathrm{p}=0,001, * * * \mathrm{p}=0,039$

CPM = lepényre korlátozódó mozaikosság; CVS = lepényszövet-mintavétel; RAT = ritka autoszomális trisomiák; sSMC = kis méretű számfeletti marker kromoszóma; T13 = 13-as trisomia; T18 = 18-as trisomia; T21 = 21-es trisomia; TFM = valódi magzati mozaikosság

rai terhességi időszakban, CVS útján került diagnosztizálásra. A ritka kromoszómaeltérések esetén a diagnózis megállapítása magasabb terhességi hétre esett, mint a gyakori aberrációk esetén $(16,1 / 13,8$ hét, $\mathrm{p}=0,000001)$. ArrayCGH-vizsgálatra sSMC-, strukturális és ritka autoszomális trisomia esetekben volt szükség (1. táblázat).

A gyakori kromoszómaeltérések 12,4\%-a bizonyult mozaikosnak (T21 9,8\%, T18 3,2\%, nemi kromoszomális rendellenesség 40\%, összesen 19 eset). A ritka, de novo kromoszóma-rendellenességekben mozaikosságot a ritka autoszomális trisomiák, az sSMC és a poliploidia esetei-

3. táblázat |A ritka, de novo kromoszóma-rendellenességek mozaikos esete és a teljes kromoszómaszerelvényt vizsgáló (genomewide) NIPT. A táblázat a ritka kromoszómaeltérésekben $(\mathrm{n}=27)$ az invazív beavatkozással kimutatott mozaikosság típusát (CPMI3, TFM4-6), a társuló major ultrahangeltéréseket és az adott rendellenességekben a 'genomewide' NIPT alkalmazása esetén várható eredményeket mutatja. A 12, lepényre korlátozódó (CPM-) esetben várhatóan álpozitív, a 9 TFM-esetból 1 esetben álnegatív eredmény született volna

\begin{tabular}{|c|c|c|c|}
\hline $\begin{array}{l}\text { Ritka, de novo mozaikos } \\
\text { kromoszómaeltérés } \\
(\mathrm{n}=21)\end{array}$ & $\begin{array}{l}\text { A mozaikosság } \\
\text { típusa az invazív } \\
\text { beavatkozás } \\
\text { alapján }\end{array}$ & $\begin{array}{l}\text { Major } \\
\text { ultrahang- } \\
\text { eltérés }\end{array}$ & $\begin{array}{l}\text { A 'genomewide' } \\
\text { NIPT várható } \\
\text { eredménye }\end{array}$ \\
\hline Poliploidia $(\mathrm{n}=4)$ & CPM2, 3 & $0 / 4$ & Álpozitív* \\
\hline $\begin{array}{l}\text { Strukturális de novo } \\
(\mathrm{n}=1)\end{array}$ & CPM1 & $0 / 1$ & Álpozitív \\
\hline $\begin{array}{l}\text { Ritka autoszomális } \\
\text { trisomia }(\mathrm{n}=7)\end{array}$ & CPM1 & $0 / 7$ & Álpozitív \\
\hline $\begin{array}{l}\text { Ritka autoszomális } \\
\text { trisomia }(\mathrm{n}=7)\end{array}$ & TFM4-6 & $5 / 7$ & $\begin{array}{l}\text { Valós pozitív } \\
\text { ( } 1 \text { esetben } \\
\text { álnegatív**) }\end{array}$ \\
\hline $\operatorname{sSMC}(\mathrm{n}=2)$ & TFM4, 6 & $1 / 2$ & Valós pozitív \\
\hline
\end{tabular}

( *a poliploidia eseteit jelenleg csak az SNP-alapú nem invazív tesztelés detektálja, * *álnegatív eset: a 9-es trisomia TFM5-ös típusa)

CPM = lepényre korlátozódó mozaikosság; NIPT = nem invazív praenatalis tesztelés; SNP = egyszeres nukleotidpolymorphysmus; sSMC = kis méretű számfeletti marker kromoszóma; TFM = valós magzati mozaikosság ben mutattunk ki (2l eset, 77,8\%,p = 0,001). Az összesen 40 mozaikos esetből $17(42,5 \%)$ lepényre korlátozódott (CPM). A lepényszövet-mintavételek 2,7\%-a (36/1334), a magzatvízminták 1\%-a (12/1170) bizonyult mozaikosnak (2. táblázat).

Megvizsgáltuk anyagunkban a ritka, de novo kromoszóma-rendellenességek mozaikos eseteiben a teljes kromoszómaszerelvényt vizsgáló, nem invazív szürőteszt alkalmazásának elméletileg várható eredményét (3. táblázat). A 12 CPM-esetben major ultrahangeltérés nem volt kimutatható, és a 'genomewide' NIPT várhatóan diszkordáns, álpozitív eredménnyel járt volna $(12 / 27=$ 44\%). A TFM-esetek jellemzően szervi ultrahangeltéréssel társultak, és 1 álnegatív eset kivételével ( $1 / 27$ = 3,7\%,

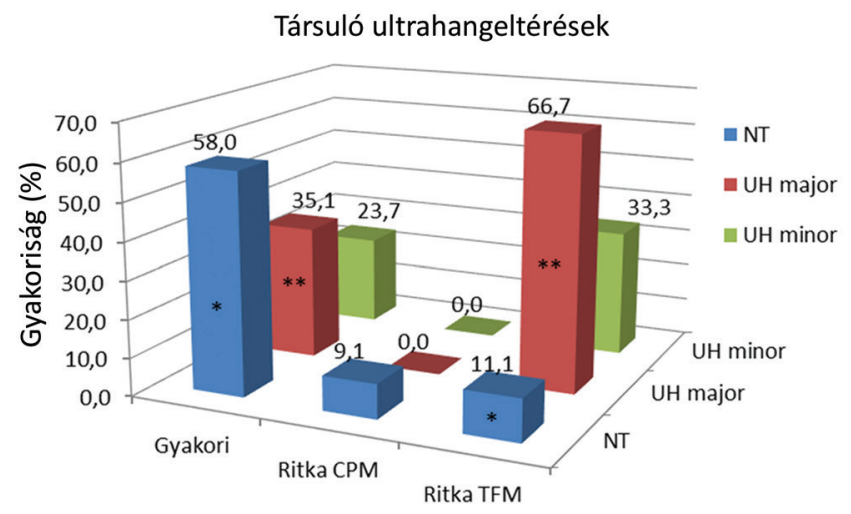

2. ábra

A gyakori és a ritka kromoszóma-rendellenességekhez társuló praenatalis ultrahangeltérések. A gyakori autoszomális trisomiákhoz (gyakori; T21, T18, T13) és a ritka, de novo kromoszómarendellenességekhez, a lepényre korlátozódó (ritka CPM) és a valódi magzati mozaikosságban (ritka TFM) társuló ultrahangeltérések (tarkóredő-vastagság [NT] >3 mm; major szervi rendellenességek; második trimeszteri minor jelek) gyakorisága (\%)

${ }^{*} \mathrm{p}=0,006,{ }^{*} \mathrm{p}=0,047$

$\mathrm{CPM}$ = lepényre korlátozódó mozaikosság; NT = tarkóredővastagság; $\mathrm{T} 13=13$-as trisomia; $\mathrm{T} 18=18$-as trisomia; $\mathrm{T} 21=$ 2l-es trisomia; TFM = valódi magzati mozaikosság; $\mathrm{UH}=$ ultrahang 
4. táblázat $\mid$ A lepényre korlátozódó és a valódi magzati mozaikosság klinika különbségeinek bemutatása a ritka autoszomális trisomiák esetein keresztül. A ritka autoszomális trisomiák 7-7 esetében észlelt különbségek (anyai életkor, társuló ultrahangeltérések, egészsé ges élveszülés) lepényre korlátozódó (CPM) és valódi magzat mozaikosságban (TFM). A major ultrahangeltérések döntően facialis dysmorphismus és korai, méhen belüli súlyretardáció voltak

\begin{tabular}{lllll}
\hline $\begin{array}{l}\text { Ritka } \\
\text { autoszomális } \\
\text { trisomiák }\end{array}$ & $\begin{array}{l}\text { Anyai } \\
\text { átlagéletkor } \\
(\text { év, 95\% CI })\end{array}$ & $\begin{array}{l}\text { Kóros } \\
\text { tarkóredő } \\
(\mathrm{NT}>3 \mathrm{~mm})\end{array}$ & $\begin{array}{l}\text { Major } \\
\text { ultrahang- } \\
\text { eltérés }\end{array}$ & $\begin{array}{l}\text { Egészséges } \\
\text { élveszülés }\end{array}$ \\
\hline CPM $(\mathrm{n}=7)$ & $\begin{array}{l}30,7 \\
(22,6-38,8) *\end{array}$ & $1 / 7$ & $0 / 7^{* *}$ & $6 / 7^{* * *}$ \\
TFM $(\mathrm{n}=7)$ & $\begin{array}{l}38,9 \\
(36,3-41,5) *\end{array}$ & $1 / 7$ & $5 / 7 * *$ & $2 / 7 * * *$ \\
\hline
\end{tabular}

${ }^{*} \mathrm{p}=0,038,{ }^{*} \mathrm{p}=0,049, * * * \mathrm{p}=0,049$

$\mathrm{CI}=$ konfidenciaintervallum; CPM = lepényre korlátozódó mozaikosság; NT = tarkóredő-vastagság; TFM = valódi magzati mozaikosság

a 9-es trisomia TFM5-ös típusa) feltételezhetően valós pozitív eredményt szolgáltatott volna a szürés. Ráadásul 2 ritka autoszomális trisomia esetben (a 12-es trisomia $45 \%$-os mozaikossággal és a 20 -as trisomia $46 \%$-os mozaikossággal magzatvízból) a 'genomewide' NIPT ultrahangeltérés nélkül is kimutatta volna a valós magzati kromoszómaeltérést $(2 / 27=7,4 \%)$.

A társuló ultrahangeltéréseket a 2. ábrán foglaltuk öszsze. Down-szindrómában nem volt különbség a mozaikos (TFM) és a nem mozaikos esetek ultrahangeltérései között. A 3 gyakori trisomiában együttesen kóros NT 58\%-ban, major rendellenesség 35\%-ban, minor jel 24\%ban igazolódott. A de novo, ritka kromoszómaeltérések lepényre korlátozódó formájában (CPM) ultrahangeltérés alig ábrázolódott. A TFM-esetekben kóros NT 1 esetben társult ( $11 \%, \mathrm{p}=0,006)$, míg a major rendellenességek gyakorisága $59 \%$ volt $(\mathrm{p}=0,047$, döntően facialis dysmorphismus, micrognathia, arcprofileltérések).

A 4. táblázat a CPM és a TFM klinikai különbségeit mutatja be a ritka autoszomális trisomiák esetein keresztül (7\%). Szignifikáns különbség volt kimutatható a CPM- és TFM-esetek között a társuló major magzati ultrahangeltérések és az egészséges élveszülés szempontjából $(\mathrm{p}=0,049)$. A TFM ritka autoszomális trisomia csoportban az átlag anyai életkor 38,9 év, a CPM-esetekben pedig 30,7 év volt ( $\mathrm{p}=0,038)$.

\section{Megbeszélés}

A számbeli kromoszómaeltérések, az aneuploidiák a kromoszóma-rendellenességek döntő részét képezik, és szerepet játszanak az embryo korai beágyazódási zavaraiban, a korai vetélésekben és a veleszületett fejlődési rendellenességek kialakulásában [19]. Az első trimeszter végétől általában a három gyakori trisomiát és a nemi kromoszóma-rendellenességeket észleljük. Ezen aneuploidiák keletkezésének fó oka az anyai ivarsejtképződés során, a meiosisban kialakuló non-disjunctio, így disomi- ás genetikai állományú petesejt, majd trisomiás zygota képződése. A petesejtnek a meiosis II.-ben keletkező kromoszómaszegregációs zavarai jóval gyakoribbak, mint a meiosis I.-ben keletkezők, és szorosan összefüggenek az anyai életkorral. A petefészek öregedése, az anyai életkor előrehaladása így az aneuploidiák kialakulásának legfontosabb oka [20,21].

A gyakori kromoszómaeltérések azonban az összes kromoszóma-rendellenességnek csak megközelítőleg a 80-85\%-át képezik $[9,10]$. Nem hanyagolhatók el tehát azok a ritka, újonnan kialakult, fénymikroszkópos vizsgálattal észlelhető egyéb magzati kromoszóma-rendellenességek, amelyek szintén jelentős klinikai következménnyel járhatnak, ugyanakkor kihívást is jelentenek, hiszen postnatalis következményük általában nehezen jósolható meg. Kimutatásukhoz gyakran olyan komplex genetikai módszerek szükségesek, mint a speciális FISHtechnikák vagy újabban az aCGH, amely a kromoszómák pontos szerkezeti meghatározásán túl a töréspontokat és az érintett gének listáját is megadja a további elemzéshez [22-24]. Az atípusos kromoszómaeltérések leggyakoribb csoportját a ritka autoszomális trisomiák képezik, melyek gyakran korai vetéléshez vezetnek. Az abortumok rutinszerű citogenetikai vizsgálatának hiányában ugyan nem ismert a pontos incidenciájuk, de a nemzetközi adatok arra utalnak, hogy a gyakoriságuk $0,28-0,75 \%$ lehet (anyagunkban $0,56 \%, 14$ eset) [25, 26].

A ritka kromoszómaeltérések gyakran mozaikos formában fordulnak elő. A mozaikosság keletkezésének fó biológiai oka az embryonalis fejlődés korai szakaszában kialakuló osztódási hiba a zygotában, a mitoticus nondisjunctio, majd az ezt követő postzygoticus korrekció. Az osztódási hiba a barázdálódó embryóban három sejtvonalat okoz: egy monosomiás, egy normál- és egy trisomiás sejtvonalat. A monosomiás sejtvonal életképtelen, így általában kiszelektálódik, míg a normál- és a trisomiás sejtvonal tovább fejlődik, és mint változatos szöveti eloszlású, diploid-aneuploid mozaikos embryo gyarapszik [27]. A folyamat független a szülők életkorától [28].

A praenatalis vizsgálatok során a mozaikosság aránylag gyakori, hiszen a lepényszövet-mintavételek 1-2\%-ában, míg a magzatvízminták kb. 0,1-0,3\%-ában fordul elő $[12,13]$. Anyagunkban az irodalmi adatoknál észlelt magasabb mozaikossági ráta $(2,7 \%$ és $1 \%)$ oka lehet a felismert kromoszóma-rendellenességek spektruma (a ritka autoszomális trisomiák és a marker kromoszómák is jellemzően mozaikos eloszlásúak), illetve a használt FISHmódszer érzékenysége, hiszen nagyságrendekkel nagyobb interfázisos sejtpopuláció elemzését teszi lehetővé, alacsony szintü mozaikosságot is kimutatva. Ugyanakkor más európai centrum nagy esetszámú tanulmánya is anyagunkhoz hasonló, magasabb mozaikossági arányról számolt be [29]. A sejtek és a szövetek differenciálódása a megtermékenyülést követően korán elkezdődik. Osztódási hiba esetén a normál- és a kóros sejtvonal eloszlása a lepényi és a magzati szövetek között (tehát a mozai- 
kosság típusa) függ a non-disjunctio idejétől és módjától. Korai osztódási zavar esetén a lepényi és a magzati szövetek is érintettek lehetnek, későbbi hiba esetén azonban a folyamat differenciálódhat, és vagy csak a placentaris, vagy csak a magzati kompartmentre (CPM/TFM) korlátozódhat [30]. A mozaikosság eseteiben feltételezhetően a lepényi sejtek pontos érintettsége is befolyásolja azt, hogy milyen mértékben várható a magzatban is megnyilvánuló tényleges kromoszómaeltérés (TFM) kialakulása. Egy olaszországi tanulmány 7112 lepényszövet-mintavétel retrospektív analízise során azt találta, hogy kizárólag a lepényi trophoblastsejtek érintettsége esetén (CPMl ) 5,88\%-ban, kizárólag a lepényi mesenchymalis sejtek érintettsége esetén (CPM2) 20,96\%-ban, míg mindkét lepényi sejt érintettsége esetén (CPM3) 58,97\%ban alakult ki valós magzati kromoszómaeltérés (TFM) is [31]. Ráadásul úgy tűnik, hogy a lepényi mozaikosság egyes típusai összefügghetnek a korai lepényi biokémiai faktorok anyai szérumszintjével és a terhességi komplikációkkal [32]. A szerzők azt találták, hogy míg a CPM2-es típusban a terhesség kimenetele megegyezett a normális kontrollpopulációéval, a CPM3-esetek az anyai szérumPAPP-A (pregnancy-associated plasma protein-A) alacsony szintjével jártak, jelentősen megemelkedett a koraszülés és a méhen belüli magzati súlyretardáció előfordulása. A tanulmány szerint a lepényi trophoblastés mesenchymalis sejtek együttes érintettsége (CPM3) predesztinált a rossz terhességi kimenetelre, így pontos citogenetikai karakterizálása elengedhetetlenül fontos klinikai információt szolgáltat.

Anyagunkban szembetûnő, hogy a ritka, de novo kromoszómaeltérésekben szignifikánsan gyakrabban igazoltunk fetoplacentaris mozaikosságot (poliploidia, sSMC, ritka autoszomális trisomiák), mint a gyakori kromoszómaeltérésekben $(77,8 \%$, illetve $12,4 \%)$, és az anyai életkor a gyakori trisomiákhoz hasonlóan emelkedett volt. Érdekes megfigyelés azonban, hogy ritka autoszomális trisomiában a lepényre korlátozódó mozaikosság eseteiben az anyai átlagéletkor alig 30 év volt (TFM esetén 38,9 év), ami arra utal, hogy a lepényi és a valódi magzati mozaikos esetekben más lehetett a biológiai mechanizmus (mitoticus/meioticus non-disjunctio). Fontos hangsúlyozni, hogy míg a gyakori kromoszómaeltérések mozaikos és nem mozaikos formáiban is kimutathatók a korai felismerést elősegítő, karakterisztikus praenatalis ultrahangeltérések (például kóros NT Down-, Edwards-, Patau-szindrómában, köldöksérv Edwards-szindrómában, ajak- és szájpadhasadék Patau-szindrómában), addig a ritka kromoszóma-rendellenességeknek nincsen jellemző praenatalis ultrahangeltérésük. Ugyanakkor míg anyagunkban a ritka kromoszómaeltérések jóformán alig társultak kóros NT-vel, addig gyakori volt a facialis dysmorphismus, a micrognathia és a korai, méhen belüli retardáció az ultrahangvizsgálat során. Normális NT mellett a fenti ultrahangeltérések észlelésekor így feltétlenül gondolni kell a nem szokványos, ritka kromoszómaeltérés lehetőségére, mely egyben jelentősen befolyá- solja a további ellátási preferenciákat (invazív mintavétel vs. nem invazív tesztelés).

Fontos megvizsgálni a praenatalis ellátást az elmúlt évtizedben alapjaiban megváltoztató, anyai vérból végezhető, nem invazív szűrőmódszerek és a ritka kromoszóma-rendellenességek összefüggéseit. Az újgenerációs szekvenálás alapú NIPT a kromoszómaeltérések hatékony és korai szúrésére alkalmas a 9. terhességi héttől kezdve [7]. Egy nagy metaanalízis alapján a módszer detekciós rátája a gyakori trisomiákra egyes terhességben elérte a 99\%-ot, míg az álpozitív ráta nem haladta meg a 0,14\%-ot [33]. Biológiai értelemben a módszer egy koraterhességi időszakban az anyai vérből elvégezhető direkt, tenyésztés nélküli lepényi preparátum információtartalmának felel meg, és a cytotrophoblastsejtek genetikai állományát reprezentálja. Ugyanakkor fontos hangsúlyozni, hogy míg CVS során egy vastagtü-biopsziás beavatkozás csak a lepényszövet egy kis részének random mintavételezését eredményezi, addig a NIPT a teljes lepényágyból felszabaduló DNS-fragmentumokat vizsgálja. Miután a méhlepény egész felületéról származó trophoblastsejtek DNS-'pool'-ja (a DNS/genetikai állomány összessége) kerül analízisre, a NIPT a placenta mozaikos állapotát jobban tükrözi, mint a lepényszövetmintavétel során egy bizonyos lokális helyről származó minta értékelése [34]. Ugyanakkor az invazív mintavétellel a chorionbolyhok mesenchymalis állománya is vizsgálhatóvá válik, így a NIPT-eredménnyel szemben a praenatalis diagnosztika a mozaikosság pontosabb meghatározására és prognosztikus jelentőségének megértésére ad lehetőséget. A NIPT szûrővizsgálati eredménye eltérő lehet a magzat valós genetikai állományától, tehát diszkordáns eredményt produkálhat. Ma már ismert, hogy a diszkordáns NIPT-eredmények fó oka nem maga a módszer múködési hibája, hanem a fetoplacentaris mozaikosság, mely önmagában az álpozitív esetek kb. 3050\%-áért lehet felelős [35]. A CPMl és -3 álpozitív, a TFM5 pedig jellemzően álnegatív eredményt generál [17]. Álpozitív eredmény származhat még a felszívódó ikerterhességból, az anyai CNV-kból, ritkán pedig anyai tumorból származó DNS-fragmentumokból is, míg az anyai szérumban mérhető alacsony magzati DNS-frakció nem értékelhető vizsgálati eredményt okozhat [36]. Újabban egyes munkacsoportok olyan algoritmusok fejlesztésével foglalkoznak, amelyek a fetoplacentaris mozaikosság még pontosabb meghatározását célozzák a nem invazív tesztelés során [37].

A NIPT szokásos, célzott (targeted) használata során (T21, T18, T13, nemi kromoszomális rendellenesség) azonban úgy becsülhető, hogy a kromoszóma-rendellenességek 17-25\%-a nem kerül felismerésre [38, 39]. Felmerült a módszer kiterjesztett használata egyéb genetikai kórképek, mint például a microdeletiók/duplicatiók, a ritka kromoszómaeltérések irányában, hiszen a szekvenálóplatformok és az értékelő bioinformatikai szoftverek ma már alkalmasak lehetnek az ilyen irányú felhasználásra is $[40,41]$. A ritka kromoszóma-rendellenességek 
vizsgálatára elméletileg alkalmas, teljes kromoszómaszerelvényt vizsgáló (genomewide) NIPT-technológia rendelkezésre áll, jelenleg azonban hiányoznak azok a validált klinikai adatok, melyekre a szakemberek támaszkodhatnának [42]. Egy olaszországi munkacsoport 'genomewide' NIPT alkalmazása során azt találta, hogy a célzott NIPT-tel szemben 7,4\%-kal több kromoszómarendellenességet sikerült felismerni, a szerzők így javasolták a NIPT ilyen irányú, kiterjesztett használatát [11]. Jelenleg egyetlen olyan, teljes populációt elemző tanulmány eredménye ismert, melynek során Hollandiában egy országos szürőprogram keretében teljes kromoszómaszerelvényt vizsgáló NIPT-módszert ajánlottak első vonalas szürôtesztnek (TRIDENT2) [43]. A nagy esetszámú tanulmány azt igazolta, hogy míg a gyakori trisomiák szűrővizsgálatának hatékonysága és detekciós rátája továbbra is magas maradt, addig 0,36\%-ban találtak olyan, ún. addicionális eltérést (ritka autoszomális trisomiák és strukturális rendellenességek), melyeknél magas volt a diszkordáns, álpozitív leletek aránya. A NIPT ilyen irányú, populációs szintű, teljes genomot vizsgáló felhasználása így óvatosságot igényel, mert növelheti a vetélési kockázattal is járó, invazív beavatkozások számát. A 'genomewide' NIPT akkor ajánlható praenatalis szűrőmódszer, ha a pácienst előzetesen részletesen tájékoztatták a metodika potenciális előnyeiről (a ritka kromoszómaeltérések korai felismerési lehetősége) és hátrányairól (esetleges álpozitív eredmények és következményes invazív beavatkozási igény). Anyagunkban a ritka kromoszómaeltérések 12 esete bizonyult lepényi mozaikosnak, így a 'genomewide' NIPT alkalmazása a ritka rendellenességek 44\%-ában feltételezhetően álpozitív eredményt mutatott volna. Ezen esetekben egyébként a lepényszövetmintavételezés sem tudott különbséget tenni a lepényi és a valódi magzati mozaikosság között, így amniocentesisre mindenképpen szükség volt. Ugyanakkor a 'genomewide' NIPT használata 2 olyan ritka, valós magzati kromoszóma-rendellenességet is kimutatott volna (2 ritka autoszomális trisomia eset, $7,4 \%$ ), amely nem járt praenatalis ultrahangeltéréssel, 1 ritka autoszomális trisomia esetben pedig (3,7\%) TFM5-ös típusú mozaikosság miatt álnegatív lett volna a szürési eredmény. A NIPT nem szokványos találata esetén (ritka autoszomális trisomiák, strukturális rendellenességek), amennyiben ultrahangeltérés nem társul, elsődlegesen lepényi mozaikosságra (CPM) gondoljunk, de a normális ultrahangkép sem tudja kizárni a valós magzati kromoszómaeltérés lehetőségét. Ilyen esetekben a korai lepényszövet-mintavétel kerülendő, a magzati kromoszóma valós statusának meghatározására pedig magzatvíz-mintavétel javasolt a 15. és 20. terhességi hét között. Hasonló ajánlás fogalmazható meg olyan, gyakori trisomiára pozitív NIPTeredmény esetén, amikor társuló ultrahangeltérés nem mutatható ki, és gyakori lehet a lepényi mozaikosság (például Patau-szindróma). Fontos hangsúlyozni azt is, hogy szervi ultrahangeltérések és $3,5 \mathrm{~mm}$-es értéket meghaladó magzati NT esetén a nemzetközi ajánlások továbbra is invazív beavatkozást javasolnak, hiszen ezen esetekben a NIPT hatékonysága egyértelmúen elmarad a diagnosztikus vizsgálatokétól [44, 45].

Retrospektív vizsgálatunk során 13,5\%-ban igazoltunk de novo, ritka citogenetikai kórképet, melyek 78\%-a mozaikos formában fordult elő, jellemzően társulva major, strukturális ultrahangeltéréssel, normális magzati NT mellett. Kimutatásuk arany standard módszere továbbra is a magas szintü ultrahangszưrés, az invazív mintavételezés és a pontos citogenetikai karakterizálás. A nem invazív szűrőmódszerek közül azonban a NIPT a cytotrophoblastsejt-eredetű genetikai eltérést korai terhességi korban detektálhatja apoptotikus DNS-t szekvenálva, akár megelőzve a tényleges klinikai (ultrahangos) felismerést. A 'genomewide' NIPT alkalmazása anyai vérból a korai diagnosztika alternatívája lehet, a mozaikosság gyakori jelensége azonban ebben a kórcsoportban növeli a diszkordáns eredmények veszélyét. A fetoplacentaris mozaikosság ismerete fontos klinikai információt jelent, és befolyásolhatja a klinikai döntéseket. Jelenleg nem tisztázott, hogy a szürő- és diagnosztikus módszerek milyen kombinációja a legmegfelelőbb, és többfajta praenatalis vizsgálati stratégia létezik. Egy 2020-ban publikált svéd, populációs szintű tanulmány azt találta, hogy a gyakori és a ritka kromoszóma-rendellenességek együttes kimutatása akkor a leghatékonyabb, ha a kombinált szûrés 1 : 200 kockázati értéke felett invazív beavatkozást (aCGH) végeznek, míg az 1 : 200 és 1 : 1000 közötti kockázati tartományban NIPT történt. Ez a stratégia a gyakori kromoszómaeltérések 95\%-át, a ritka kromoszómaeltérések 55\%-át mutatta ki [46].

Tanulmányunk hátrányai között meg kell említenünk, hogy vizsgálatunk retrospektív elemzés. A magyarországi szakmai protokoll nem tartalmazza az anyai vérból elvégezhető szúrővizsgálatok NEAK által finanszírozott elvégzését, ráadásul az aCGH sem finanszírozott eljárás, így a fenti módszereket csak akkor tudtuk alkalmazni, amikor a páciens azokat önköltségesen kifizette. Számos indokolt esetben (például az NT 3,5 mm felett, szervi magzati ultrahangeltérés) azonban elmaradt az aCGH használata. Az aCGH praenatalis gyakorlatban történő magyarországi bevezetésére nemrég ajánlást fogalmaztunk meg, de a módszer közfinanszírozott hazai alkalmazása jelenleg még várat magára [47]. Néhány esetben így valószínúleg nem kerültek felismerésre microdeletiók/duplicatiók, melyek a hagyományos kromoszómavizsgálat felbontási határa alatti méretûek. Munkacsoportunk ugyanakkor a leggyakoribb microdeletiós kórkép, a DiGeorge-szindróma célzott genetikai vizsgálatát FISH-módszerrel 2015 óta elvégzi, amennyiben annak ultrahangos indokai fennállnak (például magzati aortaív- és conotruncalis rendellenességek) [48].

Eredményeink felhívják a figyelmet arra, hogy a ritka kromoszóma-rendellenességek és a fetoplacentaris mozaikosság felismerése jelentős klinikai információt biztosít, mely befolyásolhatja a terhesség kimenetelét és a terhesség követésének módját. Szükséges lenne a nem- 
zetközi tapasztalatokon alapuló, akár magyarországi multicentrikus vizsgálatok eredményére támaszkodó, hazai konszenzus alapján kialakított szabályozás a nem invazív szürőmódszerek alkalmazására és az aCGH bevezetésére a praenatalis centrumokban.

Anyagi támogatás: A közlemény megírása és a kutatómunka anyagi támogatásban nem részesült.

Szerzôi munkamegosztás: T. Zs.: A közlemény megírása, az ultrahangvizsgálat és az invazív beavatkozások elvégzése. P. T. E.: A közlemény megírása, a kariotipizálás és a FISH-vizsgálatok elvégzése. B. I., S. E.: A statisztikai adatok feldolgozása és elemzése, a kariotipizálás és a FISH-vizsgálatok elvégzése. P. H.: Az aCGH-vizsgálatok elvégzése. S. J., V. G., D. J., B. A.: A közlemény véleményezése, javítása. A cikk végleges változatát valamennyi szerző elolvasta és jóváhagyta.

Érdekeltségek: A szerzőknek nincsenek érdekeltségeik.

\section{Köszönetnyilvánítás}

A szerzők köszönik a Magyar Honvédség Egészségügyi Központ Genetikai Laboratóriuma dolgozóinak áldozatos munkáját. Szintén köszönjük a szakmai együttmúködést a PentaCore Laboratóriumnak az aCGH-vizsgálatok elvégzését. Köszönjük a statisztikai analízist Acsai Károlynak.

\section{Irodalom}

[1] Papp Z. Culturing amniocytes for karyotyping. In: Papp Z. (ed.) Clinical genetics. [Magzatvízsejtek tenyésztése karyotyipizálás céljából. In: Papp Z. (szerk.) Klinikai genetika.] Golden Book, Budapest. 1995; pp. 182-188. [Hungarian]

[2] Papp C, Papp Z. Chorionic villus sampling and amniocentesis: what are the risks in current practice? Curr Opin Obstet Gynecol. 2003; 15: 159-165.

[3] P. Tardy E, Tóth A, Hajdu K, et al. Fluorescence in situ hybridization in prenatal diagnosis. First experiences. [A fluoreszcens in situ hibridizáció alkalmazása a praenatalis diagnosztikában. Elsố tapasztalatok.] Orv Hetil. 1996; 137: 523-526. [Hungarian]

[4] Findlay I, Tóth T, Matthews P, et al. Rapid trisomy diagnosis $(21,18$, and 13) using fluorescent PCR and short tandem repeats: applications for prenatal diagnosis and preimplantation genetic diagnosis. J Assist Reprod Genet. 1998; 15: 266-275.

[5] Srebniak MI, Diderich KE, Joosten M, et al. Prenatal SNP array testing in 1000 fetuses with ultrasound anomalies: causative, unexpected and susceptibility CNVs. Eur J Hum Genet. 2016; 24 : 645-651.

[6] de Ravel TJ, Devriendt K, Fryns JP, et al. What's new in karyotyping? The move towards array comparative genomic hybridisation (CGH). Eur J Pediatr 2007; 166: 637-643.

[7] Bianchi DW, Chiu RW. Sequencing of circulating cell-free DNA during pregnancy. N Engl J Med. 2018; 379: 464-473.

[8] Hui L, Hutchinson B, Poulton A, et al. Population-based impact of noninvasive prenatal screening on screening and diagnostic testing for fetal aneuploidy. Genet Med. 2017; 19: 1338-1345.

[9] Alamillo CM, Krantz D, Evans M, et al. Nearly a third of abnormalities found after first-trimester screening are different than expected: 10-year experience from a single center. Prenat Diagn. 2013; 33: 251-256
[10] Wellesley D, Dolk H, Boyd PA, et al. Rare chromosome abnor malities, prevalence and prenatal diagnosis rates from population-based congenital anomaly registers in Europe. Eur J Hum Genet. 2012; 20: 521-526.

[11] Fiorentino F, Bono S, Pizzuti F, et al. The clinical utility of genome-wide non invasive prenatal screening. Prenat Diagn. 2017; 37: 593-601.

[12] Teshima, IE, Kalousek DK, Vekemans MJ, et al. Canadian multicenter randomized clinical trial of chorion villus sampling and amniocentesis. Chromosome mosaicism in CVS and amniocentesis samples. Prenat Diagn. 1992; 12: 443-466.

[13] Hahnemann JM, Vejerslev LO. European collaborative research on mosaicism in CVS (EUCROMIC) - fetal and extrafetal cell lineages in 192 gestations with CVS mosaicism involving single autosomal trisomy. Am J Med Genet. 1997; 70: 179-187.

[14] Papavassiliou P, Charalsawadi C, Rafferty K, et al. Mosaicism for trisomy 21: a review. Am J Med Genet A 2015; 167: 26-39.

[15] Tucker ME, Garringer HJ, Weaver DD. Phenotypic spectrum of mosaic trisomy 18: two new patients, a literature review, and counseling issues. Am J Med Genet A. 2007; 143: 505-517.

[16] Xie X, Tan W, Li F, et al. Diagnostic cytogenetic testing following positive noninvasive prenatal screening results of sex chromosome abnormalities: report of five cases and systematic review of evidence. Mol Genet Genomic Med. 2020; 8: el297.

[17] Grati FR, Malvestiti F, Ferreira JC, et al. Fetoplacental mosaicism: potential implications for false-positive and false-negative noninvasive prenatal screening results. Genet Med. 2014; 16: 620-624.

[18] Silva M, de Leeuw N, Mann K, et al. European guidelines for constitutional cytogenomic analysis. Eur J Hum Genet. 2019; 27: 1-16.

[19] van den Berg MM, van Maarle MC, van Wely M, et al. Genetics of early miscarriage. Biochem Biophys Acta 2012; 1822: 19511959.

[20] Fragouli E, Alfarawati S, Spath K, et al. The origin and impact of embryonic aneuploidy. Hum Genet. 2013; 132: 1001-1013.

[21] Nagaoka SI, Hassold TJ, Hunt PA. Human aneuploidy: mechanisms and new insights into an age-old problem. Nat Rev Genet. 2012; 13: 493-504.

[22] Baptista J, Mercer C, Prigmore E, et al. Breakpoint mapping and array CGH in translocations: comparison of a phenotypically normal and abnormal cohort. Am J Hum Genet. 2008; 82: $927-$ 936.

[23] Tidrenczel Z, P Tardy E, Sarkadi E, et al. Prenatally diagnosed case of Pallister-Killian syndrome. [Praenatalisan diagnosztizált Pallister-Killian-szindróma esete.] Orv Hetil. 2018; 159: 847852. [Hungarian]

[24] Marle N, Martinet D, Aboura A, et al. Molecular characterization of 39 de novo sSMC: contribution to prognosis and genetic counselling, a prospective study. Clin Genet. 2014; 85: 233244.

[25] He Y, Liu YH, Xie RG, et al. Rare autosomal trisomies on noninvasive prenatal testing: not as adverse as expected. Ultrasound Obstet Gynecol. 2019; 54: 838-839.

[26] Scott F, Bonifacio M, Sandow R, et al. Rare autosomal trisomies: important and not so rare. Prenat Diagn. 2018; 38: 765-771.

[27] Taylor TH, Gitlin SA, Patrick JL, et al. The origin, mechanisms, incidence and clinical consequences of chromosomal mosaicism in humans. Hum Reprod Update 2014; 20: 571-581.

[28] Antonarakis SE, Avramopoulos D, Blouin JL, et al. Mitotic errors in somatic cells cause trisomy 21 in about $4.5 \%$ of cases and are not associated with advanced maternal age. Nat Genet. 1993; 3: $146-150$

[29] Malvestiti F, Agrati C, Grimi B, et al. Interpreting mosaicism in chorionic villi: results of a monocentric series of 1001 mosaics in chorionic villi with follow-up amniocentesis. Prenat Diagn. 2015; 35: 1117-1127. 
[30] Grati FR. Chromosomal mosaicism in human feto-placental development: implications for prenatal diagnosis. J Clin Med. 2014; 3: 809-837.

[31] Battaglia P, Baroncini A, Mattarozzi A, et al. Cytogenetic followup of chromosomal mosaicism detected in first-trimester prenatal diagnosis. Prenat Diagn. 2014; 34: 739-747.

[32] Toutain J, Goutte-Gattat D, Horovitz J, at al. Confined placental mosaicism revisited: impact on pregnancy characteristics and outcome. PLoS ONE 2018; 13: e0195905.

[33] Gil MM, Accurti V, Santacruz B, et al. Analysis of cell-free DNA in maternal blood in screening for aneuploidies: updated metaanalysis. Ultrasound Obstet Gynecol. 2017; 50: 302-314.

[34] Van Opstal D, Eggenhuizen GM, Joosten M, et al. Noninvasive prenatal testing as compared to chorionic villus sampling is more sensitive for the detection of confined placental mosaicism involving the cytotrophoblast. Prenat Diagn. 2020; 40: 13381342.

[35] Hartwig TS, Ambye L, Sørensen S, et al. Discordant non-invasive prenatal testing (NIPT) - a systematic review. Prenat Diagn. 2017; 37: 527-539.

[36] Hui 1, Bianchi DW. Fetal fraction and noninvasive prenatal testing: what clinicians need to know. Prenat Diagn. 2020; 40: 155163.

[37] Brison N, Neofytou M, Dehaspe L, et al. Predicting fetoplacental chromosomal mosaicism during non-invasive prenatal testing. Prenat Diagn. 2018; 38: 258-266.

[38] Norton ME, Jelliffe-Pawlowski LL, Currier RJ. Chromosome abnormalities detected by current prenatal screening and noninvasive prenatal testing. Obstet Gynecol. 2014; 124: 979-986.

[39] Vogel I, Tabor A, Ekelund C, et al. Population-based screening for trisomies and atypical chromosomal abnormalities: improving efficacy using the combined first trimester screening algorithm as well as individual risk parameters. Fetal Diagn Ther. 2019; 45: 424-429.

[40] Lefkowitz RB, Tynan JA, Liu T, et al. Clinical validation of a noninvasive prenatal test for genomewide detection of fetal copy number variants. Am J Obstet Gynecol. 2016; 215: 227.el-227. el6.
[41] Pertile MD, Halks-Miller M, Flowers N, et al. Rare autosomal trisomies, revealed by maternal plasma DNA sequencing, suggest increased risk of feto-placental disease. Sci Transl Med. 2017; 9: eaan 1240.

[42] Rose NC, Kaimal AJ, Dugoff L, et al. Screening for fetal chromosomal abnormalities: ACOG Practice Bulletin, Number 226. Obstet Gynecol. 2020; 136: e48-e69.

[43] van der Meij KR, Sistermans EA, Macville MV, et al. TRIDENT-2: National implementation of genome-wide non-invasive prenatal testing as a first-tier screening test in the Netherlands. Am J Hum Genet. 2019; 105: 1091-1101.

[44] Beulen L, Faas BH, Feenstra I, et al. Clinical utility of non-invasive prenatal testing in pregnancies with ultrasound anomalies. Ultrasound Obstet Gynecol. 2017; 49: 721-728.

[45] Reimers RM, Mason-Suares H, Little SE, et al. When ultrasound anomalies are present: an estimation of the frequency of chromosome abnormalities not detected by cell-free DNA aneuploidy screens. Prenat Diagn. 2018; 38: 250-257.

[46] Iwarsson E, Conner P. Detection rates and residual risk for a postnatal diagnosis of an atypical chromosome aberration following combined first-trimester screening. Prenat Diagn. 2020; 40: 852-859.

[47] Tidrenczel Zs, P Tardy E, Pikó H, et al. Chromosomal microarray comparative genome hybridization (arrayCGH) in prenatal settings. Proposal for Hungarian application in clinical practice. [A microarray-komparatív genomhibridizálás (arrayCGH) praenatalis alkalmazása. Javaslat a hazai bevezetésre.] Orv Hetil. 2019; 160: 484-493. [Hungarian]

[48] Tidrenczel Zs, Tardy EP, Sarkadi E, et al. Prenatal screening and diagnosis of DiGeorge syndrome. [A DiGeorge-szindróma prenatális szűrése és diagnosztikája]. Magy Nőorv Lap. 2019; 82: 174-183. [Hungarian]

(Tidrenczel Zsolt dr., Budapest, Podmaniczky u. 111., 1062 e-mail: tidrenc@hotmail.com)

\section{"Semper plus metuit animus ignotum malum." (A bajtól, ha nem ismeri, mindig jobban fél a lélek.)}

A cikk a Creative Commons Attribution 4.0 International License (https://creativecommons.org/licenses/by/4.0/) feltételei szerint publikált Open Access közlemény, melynek szellemében a cikk bármilyen médiumban szabadon felhasználható, megosztható és újraközölhető, feltéve, hogy az eredeti szerző és a közlés helye, illetve a CC License linkje és az esetlegesen végrehajtott módosítások feltüntetésre kerülnek. (SID_1) 